\title{
Regional land use efficiency and nutritional quality of protein production
}

\author{
Ilkka Leinonen ${ }^{\mathrm{a}, \mathrm{b}, *}$, Pietro P.M. Iannetta ${ }^{\mathrm{c}}$, Michael MacLeod ${ }^{\mathrm{b}}$, Robert M. Rees ${ }^{\mathrm{b}}$, Wendy Russell ${ }^{\mathrm{d}}$, \\ Christine Watson ${ }^{\mathrm{e}}$, Andrew P. Barnes ${ }^{\mathrm{b}}$
}

${ }^{a}$ Natural Resources Institute Finland (LUKE), Latokartanonkaari 9, 00790, Helsinki, Finland

${ }^{\mathrm{b}}$ Scotland's Rural College (SRUC), West Mains Road, Edinburgh, EH9 3JG, UK

${ }^{\mathrm{c}}$ The James Hutton Institute, Invergowrie, Dundee, DD2 5DA, UK

${ }^{\mathrm{d}}$ The Rowett Institute, University of Aberdeen, Aberdeen, AB24 3FX, UK

' Scotland's Rural College (SRUC), Craibstone Estate, Aberdeen, AB21 9YA, UK

\section{A R T I C L E IN F O}

\section{Keywords:}

Amino acids

Climate change

Food production

Livestock

Land use

Protein

\begin{abstract}
A B S T R A C T
Strategies for achieving environmental sustainability of protein production vary regionally. In this study, a framework was applied that would quantify a region-specific contribution to global protein supply with a special focus on protein quality i.e. essential amino acid composition. The framework was applied in Scotland and showed that high-quality human-edible protein from that region currently emerges mainly from animal production. Considering future protein scenarios, the land requirement for pulses for producing a certain amount of essential amino acids in Scotland would be similar to the land requirement for potentially human-edible feeds needed in cattle production. Reducing the current use of agricultural by-products in livestock feeding would considerably increase the land use demand for other, potentially human edible feed crops.
\end{abstract}

\section{Introduction}

The Intergovernmental Panel on Climate Change (IPCC) recent Special Report (IPCC, 2018), recognizes the urgent need to limit the global warming to $1.5{ }^{\circ} \mathrm{C}$ above pre-industrial levels, which would require, "rapid, far-reaching and unprecedented changes in all aspects of society". It is well known that food production, and especially the livestock industry is a major source of greenhouse gas (GHG) emissions, and has also other environmental impacts such as eutrophication, acidification, biosecurity issues and loss of biodiversity. (Nijdam et al., 2012; Gerber et al., 2013). However, it is not an easy task to reduce the environmental impacts of agricultural systems, especially because global population growth and improvements in wealth are predicted to continue during the coming decades, and food demand, including the demand for high-quality protein coming from livestock, is expected to increase considerably.

As a result of the environmental concerns, it has been suggested that substituting animal products with plant products in diets could be an effective way to reduce greenhouse gas emissions and agricultural land use demand, minimize nutrient losses to the environment and improve human health (Westhoek et al., 2011; Röös et al., 2017; Chaudhary et al., 2018; IPCC, 2018). Although the amount of current global crop production could in theory fulfill the global demand for food energy, providing a high-quality plant-based food supply with all essential nutrients for the growing global population is challenging. The supply of high-quality protein may be considered as a central role of livestock production. Although the global quantity of human-edible plant-based protein production greatly exceeds the animal-based protein (Leinonen et al., 2019), plant protein quality is distinctly different from that of animal protein (e.g. Ferreira et al., 2005). In order to fulfill the nutritional demand of the global population, the balance of amino acids in the supplied protein is a critical factor (e.g. Moya, 2016; Wang and Galili, 2016; Ritchie et al., 2018; Leinonen et al., 2019). The amino acid concentration of different animal and plant-based proteins varies considerably, and this is especially a concern in the case of certain essential amino acids that cannot be produced in the human body, and therefore must be obtained from food (e.g. Lizarazo, 2015; Foyer et al., 2016). Amongst the main global food crops, many cereal species have a relatively low concentration of the essential amino acid lysine, despite their relatively high protein content. Therefore, cereal-based diets must be supplemented by other, lysine-rich foods. High protein legume grains such as beans and peas are rich in lysine, but when compared to meat, they present low levels of essential sulfur containing amino acids (i.e. methionine and cysteine). This poses a challenge when legume grains are considered as a direct replacement for animal protein.

In a recent study on global protein supply, Leinonen et al. (2019)

\footnotetext{
* Corresponding author. Natural Resources Institute Finland (LUKE), Latokartanonkaari 9, 00790, Helsinki, Finland.

E-mail address: ilkka.leinonen@luke.fi (I. Leinonen).
} 
found that the currently available protein sources which can also be technically considered as primary sources of lysine are largely limited to animal products and soybeans: the latter being currently used almost entirely as animal feed, while the amount of lysine obtained from other "protein crops" such as beans and peas is currently far below the global human demand. Current production of plant-based protein could meet the global lysine demand if soya (Glycine $\max$ ) is targeted towards human consumption, instead of using it as animal feed. However, soya may not be considered as a sustainable option for solving the global lysine supply problem due to geographically limited production areas and related issues of food security. Increased use of soya would also conflict the "crop diversification" agenda in improving resilience of agricultural production (Lin, 2011).

Leinonen et al. (2019) concluded that replacing animal protein and soya with other lysine-rich protein crops would need major changes in the structure of global agri-food systems. Following the alarmingly short timescale required for rapid reduction of GHG emissions, proposed by the IPCC (2018), it will be necessary to rely largely on the application of existing technologies and improvements in current agricultural production systems and associated processing capacities and methodologies. Due to the highly variable production environment, including differences in climate and soil conditions, socio-economic conditions and cultural issues, pathways to sustainable protein production vary significantly around the globe. Therefore, region-specific strategies are needed to help solve the global protein problem. For many regions it can be expected that increasing plant-based protein production is possible in some form. Equally, it is also likely that there will be regions where plant protein production will be restricted to lowquality or non-human edible protein that can only be utilized as livestock feed. Furthermore, it is important to consider the link between regional protein production and the overall global protein supply. For example, it may be argued that regional changes in protein production should not reduce the finite global supply of essential amino acids required to meet the increased demand from a growing population.

The aim of this study was to apply a mechanistic agricultural modelling framework, local land use and agricultural production data and nutritional information for development of a regional protein balance, and to demonstrate a contribution of a selected region to global protein supply. This accounting would include the quantity, quality (amino acid content) and land use requirement of the protein production (Fig. 1). This calculation method is suitable for assessing the potential alternative protein production strategies, for example shifting from animal-based protein towards plant-based protein production as a result of changing demand or improving the resource efficiency of animal-based production - and without compromising the quantity or quality of the produced protein or increasing the land-use pressure associated with protein production.

In this study, Scotland is used as an example of a region that produces a significant amount of protein for human consumption. Detailed or consistent country-specific statistics on protein balances such as imports and exports of protein for regions like Scotland are not available in national or international databases such as FAOSTAT, which emphasizes the need for an analytical calculation framework. There are several aspects that make current protein production in Scotland different from that of many other western European countries, and some of these aspects may affect the future potential of production of plantbased vs. animal-based protein. These specific features include: firstly, production of many arable crop species is limited by specific pedo-climatic conditions. Secondly, despite its relatively small size, there is a considerable geographical variation in land capability across Scotland (JHI, 2019) such that livestock production currently forms a large part of the overall human-edible protein production in Scotland. As Scottish livestock production is largely roughage-based, i.e. feed is produced on land which cannot be used for production of arable commodities, it can be carried out without compromising human food production (see Wilkinson, 2011). Thirdly, a large part of the arable crop production area in Scotland is utilized by the alcohol industry (mainly for whisky, other spirits and beer), vegetable oil (mainly rapeseed, Brassica napus) production, and cereal production for animal consumption. However, from the distillery, brewing and oil industries, a considerable number of co-products are available for potential use as livestock feed. These supply chains, or networks, present a suite of unique links (Leinonen et al., 2018a).

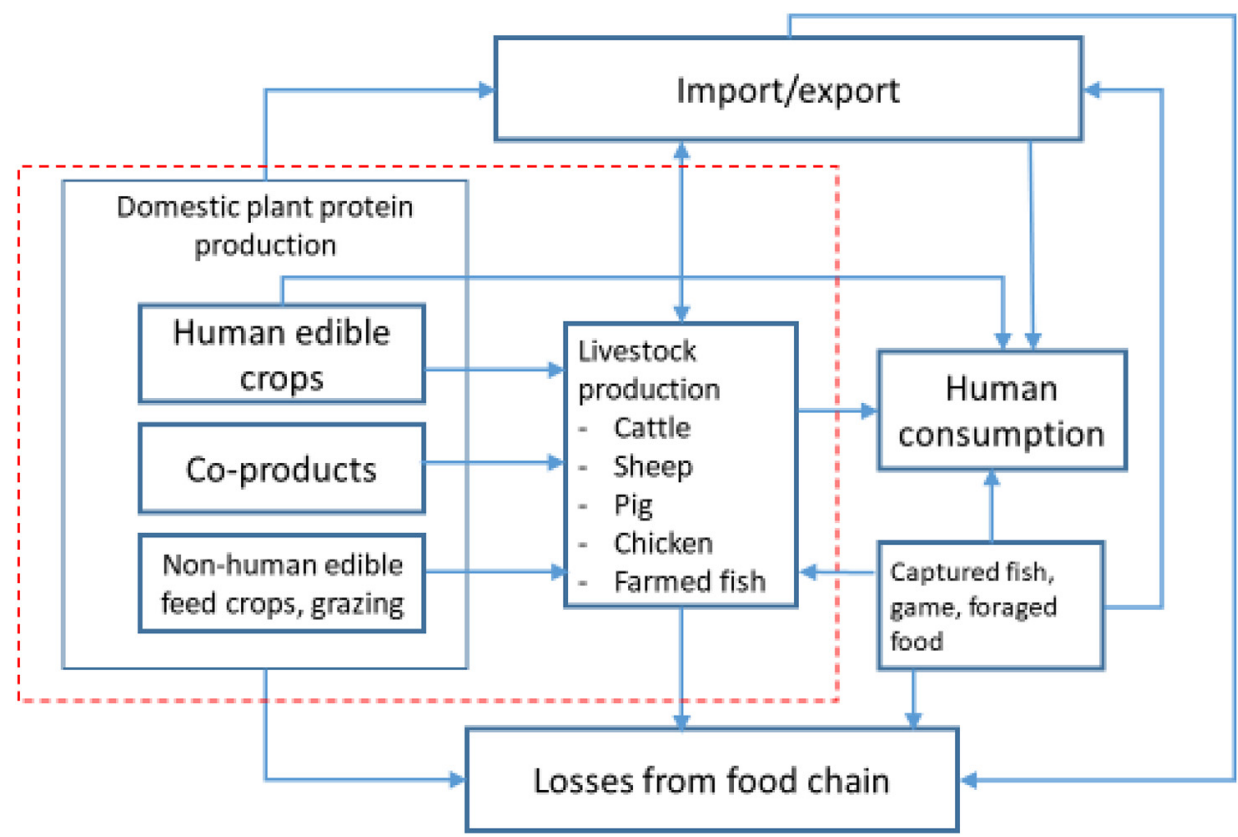

Fig. 1. Outline of the regional (Scotland) protein balance and protein flows. The dotted red rectangle indicates the main focus of this study. (For interpretation of the references to colour in this figure legend, the reader is referred to the Web version of this article.) 


\section{Material and methods}

\subsection{Current protein balance in Scotland}

The current protein balance of agricultural production in Scotland was quantified using mechanistic modelling and combining publicly available datasets of crop production areas, crop yields, livestock numbers and nutritional information on the main agricultural products. The area and yield of main crops and the area of grassland in Scotland were specified using the Scottish Government (2019) database "Economic Report on Scottish Agriculture" for the year 2015 (the latest year with complete datasets available), together with the University of Edinburgh datacenter EDINA (2018) agricultural census data and other sources (SRUC, 2019). The yields of the crops used as livestock feed but not grown in Scotland (e.g. South American soya beans and European maize grains) were obtained from the Food and Agriculture Organization of the United Nations FAOSTAT (2018) database. When estimating the land requirement for livestock feed production, mass allocation (per tonne of dry weight) was used to quantify the land use of specific feed ingredients in cases where there are multiple products coming from the same crop (e.g. one tonne of rapeseed oil had the same land requirement as one tonne of rapeseed meal, one tonne of soya oil the same requirement as one tonne of soya bean meal, and one tonne of barley grain the same requirement as one tonne of distillery by-product).

The land requirement for animal-based protein production is almost entirely determined by the area of agricultural feed production. Therefore, for the protein balance calculations, it is necessary to know the amount and composition of the feed consumed by the animals. In order to allow consistent assessment of the livestock production systems in Scotland, mechanistic model simulations were used to quantify both the protein outputs and feed inputs of different livestock production systems. The inputs and outputs of the main livestock species in Scotland, namely dairy cattle (producing milk and beef), beef cattle, sheep (hill sheep, upland sheep, lowland sheep), pigs and chickens, were quantified using the MS Excel-based Scottish Agricultural Emission Model (SAEM, MacLeod et al., 2017; Leinonen et al., 2018b). Minor livestock species such as farmed deer were not included in this study, as their contribution to the total protein production in Scotland was considered to be minimal. The livestock component of SAEM is based on GLEAM, the Global Livestock Environmental Assessment Model, which was developed by the Food and Agriculture Organization of the United Nations (FAO, 2017, 2018; MacLeod et al., 2018). The model allows the key characteristics of the livestock populations (e.g. herd structures, animal performance and feed composition) to be applied in the calculations of nutrient and energy inputs and protein outputs. Details of the model and its inputs are given in Supplementary Material. Also links to all publicly available datasets used in the livestock model can be found in Supplementary Material.

Fish farming (mainly Atlantic salmon Salmo salar and to a lesser extent rainbow trout Oncorhynchus mykiss) is also an important source of protein produced in Scotland. Although the actual fish production mainly occurs in sea cages, this industry can be seen as being largely "land based", because a significant part of the feed is coming from field crops, and therefore contributes to agricultural land use. Fish production is not included in the SAEM model, so therefore a simpler, purely data-based approach was used to quantify the protein outputs and feed consumption of fish production. The production data (i.e. tons of fish produced in 2015 and the feed conversion ratio) were obtained from the Marine Scotland Science (2017) Scottish Fish Farm Production Survey, and the composition of fish feed was estimated based on scientific literature (Ytrestøyl et al., 2015).

The crop production data and the outputs of the livestock model were applied to quantify the production of total human-edible protein and the content of human-edible essential amino acids using the following calculation framework. First, the human-edible fraction of each of the crop and animal products was estimated. For crops, this was mainly based on the "medium" protein scenario by Ertl et al. (2015) and data from the United States Department of Agriculture (USDA) food composition database (USDA, 2018). The uncertainties related to quantifying the 'human edibility' are explored in the uncertainty analysis (see below). Second, protein concentration of the human-edible fraction of each product was calculated based on the USDA food composition database. In the case of products that were mainly intended for livestock feed, the Feedipedia (2018) database was used to determine the protein concentration. Third, the total production (tonnes per year) of human edible protein in Scotland was specified as follows (Leinonen et al., 2019):

$H E P r_{i}=\operatorname{Prod}_{i} \times H E_{i} \times P r_{i}$

Where $H E P r_{i}$ is the annual production (tons per year) of human edible protein from source $i$ (specified by crop species or type of animal product), $\operatorname{Prod}_{i}$ is the annual production (tonnes per year) of the protein source $i, H E_{i}$ is the human edible fraction of the protein source $i$ and $P r_{i}$ is the protein concentration of the protein source $i$.

Concentrations of essential amino acids (isoleucine, leucine, lysine, tryptophan, threonine, valine, total sulfur amino acids, total aromatic amino acids) were calculated using data from the USDA (2018) database and the Feedipedia (2018) database. As shown by Leinonen et al. (2019), lysine is the most limiting amino acid in crop-based protein production, especially in regions where cereals are the main crop products. The total production (tons per year) of lysine was specified as follows (Leinonen et al., 2019):

$\operatorname{HELys}_{i}=\operatorname{Prod}_{i} \times H E_{i} \times \operatorname{Pr}_{i} \times \operatorname{Lys}_{i}$

Where HELys $s_{i}$ is the annual production (tonnes per year) of human edible lysine from source $i$ (specified by crop species or type of animal product), $L y s_{i}$ is the lysine concentration of the protein source $i$ and other symbols are as in Eqn. (1). For other essential amino acids potentially limiting in protein crops produced in Scotland (e.g. sulfur amino acids in legumes) a similar calculation framework as above was applied.

\subsection{Land use effects of dietary scenarios}

The land requirement for the amino acids and energy coming from different food items produced in Scotland was determined, and this information was used to explore alternative dietary scenarios and their possible combinations. When quantifying the land area needed to meet the demand for human nutrition, it is not sufficient to consider the lysine, any other amino acid, total protein, or any other single nutrient separately. The total dietary energy demand is the key factor in human nutrition, and therefore the energy supply must be accounted for when assessing future changes in food production. For this reason, the supply of dietary energy was also included in the analyses of this study. The starting point of this analysis was that although human lysine demand can be met with a relatively small amount of lysine-rich protein sources such as animal products or legumes, additional energy to meet human metabolic demand must be obtained from other sources, and the combination of all different foods in diets determines the total energy and nutrient intake. This approach would allow direct comparison, for example, between animal or plant-based diets, or their combinations.

In this study, the land requirement of different combinations of food items was quantified such that the demand of both lysine and energy would be fulfilled. In reality, infinite number of possible food scenarios could potentially fulfill these requirements. Therefore, the calculations in this study concentrated only on 'extreme' scenarios that would minimize the land use needed for food production. In these scenarios, the primary lysine source was either based on (1) animal protein (beef grown in Scotland), (2) domestic legumes (bean Vicia faba grown in Scotland), or (3) soya (all imported to Scotland). Finally, in order to investigate the importance of composition of livestock feed, an additional animal protein scenario was applied (4). In this scenario, instead 


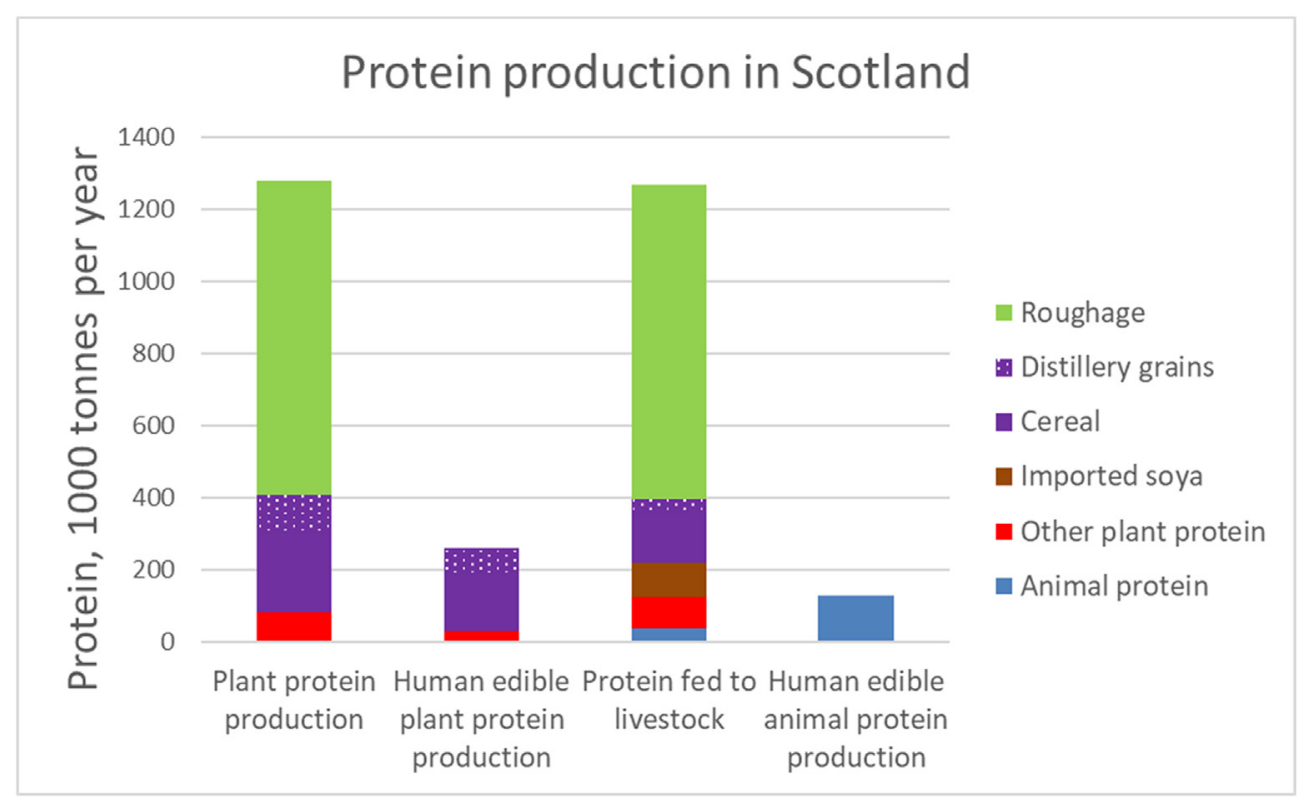

Fig. 2. Protein production in Scotland (1000 t y-1), aggregated by source and use (2015).

of using current beef cattle diets (which include agricultural by-products), an alternative feed composition was formulated, where all byproducts in the diet were replaced by human edible feed ingredients (see details below).

In addition to simplicity, there are two other advantages in using this single-source approach. First, the consequences of dietary choices (e.g. shift from animal protein to plant protein) on land requirement could be directly explored. Second, the final outcomes of the calculations would be additive, i.e. these results based on the extreme dies could be applied proportionally, so any combination of these diets could be easily explored.

Again, for simplicity, only one other crop species, namely wheat (Triticum aestivum, one of the most important energy crops in the UK and globally), was assumed to provide the additional food energy required by humans in the analyzed diets. Due to its very high yield of metabolizable energy, wheat can be expected to be the crop that would need the lowest land area for providing food energy in Scotland, consistently with the target of the scenarios that aim to minimize the agricultural land requirement.

Combination of wheat with either beef, beans or soya was specified so that both the lysine and energy intake would reach their minimum daily requirement (and sufficient quantities of other essential amino acids and total protein are also provided). A simple linear programming procedure was applied to formulate these intakes. Linear programming (using MS Excel Solver) was also used to formulate a beef cattle diet where the distillery by-products and rapeseed meal (oil industry byproducts) were replaced by a combination of soya bean meal (as protein source) and barley (Hordeum vulgare) grains (as energy source) so that the protein and energy contents of the diet remained unchanged.

To calculate the overall energy and limiting nutrient demand of humans, the recommended intake of lysine was determined to be $30 \mathrm{mg} \mathrm{kg}^{-1}$ (body weight) $\mathrm{d}^{-1}$ and the recommended intake of sulfur amino acids $15 \mathrm{mg} \mathrm{kg}^{-1}$ (body weight) $\mathrm{d}^{-1}$ (FAO/WHO/UNU, 2007). For a $70 \mathrm{~kg}$ adult (used as an indicator of nutrient requirement of a single person), this would mean $2.1 \mathrm{~g}$ lysine intake and $1.05 \mathrm{~g}$ sulfur amino acid intake per day. The metabolizable energy concentration of different food products was also obtained from the USDA food composition database (USDA, 2018). For the calculations of the energy demand of humans, the recommended daily intake was determined to be $9250 \mathrm{~kJ}$ person ${ }^{-1}$ day $^{-1}$ (British Nutrition Foundation, 2016).

\subsection{Uncertainty analysis}

Considerable uncertainties can be expected in the estimated land requirement for amino acid production, and the magnitude of such uncertainties need to be known when analysing the results of the scenarios. Many of the assumptions made in this study are qualitative rather than quantitative (e.g. allocation rules, determining the concept 'human edibility', overall formulation of the scenarios) and therefore their numeric assessment is not possible. Instead, the consequences of these assumptions are discussed in the Discussion section below. However, the land use scenarios applied here are based on rather simple quantitative calculations, and therefore the uncertainty of the results can be estimated analytically on the basis of the expected variation in the input variables. For this purpose, Equation (2) was slightly modified to show the Coefficients of Variation $(\mathrm{CoV})$ of the output and the inputs:

$\operatorname{CoV}_{L y S Y}^{2}=\mathrm{CoV}_{Y}^{2}+\operatorname{CoV}_{\mathrm{Pr}}^{2}+\operatorname{CoV}_{H E}^{2}+\operatorname{CoV}_{L y s}^{2}$

Where $\operatorname{CoV}_{L y s}$ is the Coefficient of Variation of the lysine yield (tonnes per hectare) and $\operatorname{CoV}_{Y}$, $\operatorname{CoV}_{P r}$, $\mathrm{CoV}_{H E}$ and $\mathrm{CoV}_{L y s}$ the Coefficients of Variation of the inputs dry matter yield per hectare, protein concentration of the dry matter, human edible fraction of the protein and lysine concentration of the protein, respectively. The variations of the input data were obtained from the same sources as the baseline values used in the scenarios, and the obtained estimates of this variations and the uncertainties of the outputs are explained in the Results section below.

\section{Results}

\subsection{Protein balance of Scotland}

The production of total plant and animal-based protein in Scotland is presented in Fig. 2. In this figure (and elsewhere in the paper) "plant protein" means protein that can be used either for human or livestock consumption. It should be noted that the actual "biological" protein output would be much higher since the data shown in Fig. 2 excludes the protein content of most crop residues, trees, other forest plants, weeds etc. A similar principle is applied for animal protein. For landbased animals, only the protein content of the edible carcass is considered here, so the "total animal protein" equals the human edible 


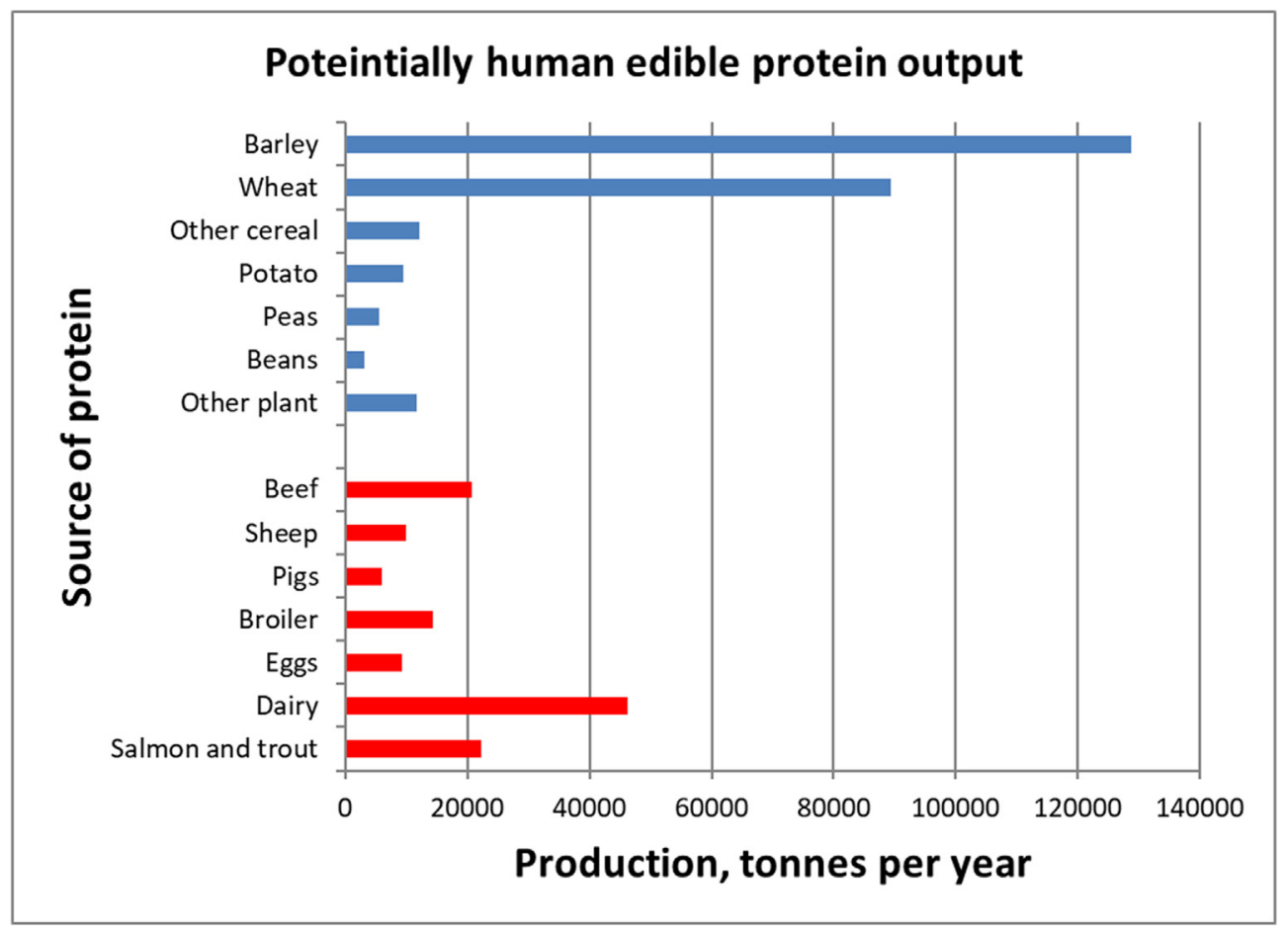

Fig. 3. Human edible protein production for potential food and feed use in Scotland (2015). The primary products (plant-based) are shown in blue colour and secondary products (animal-based) in red colour. (For interpretation of the references to colour in this figure legend, the reader is referred to the Web version of this article.)

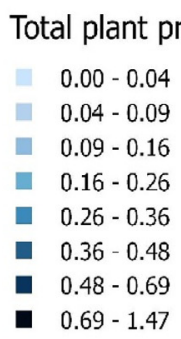

Human edible plant protein, $t /$ ha/year

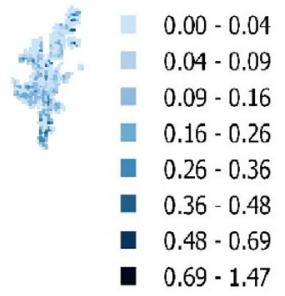

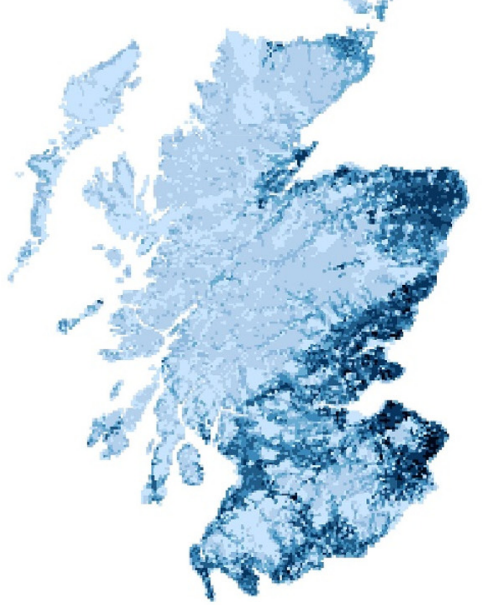

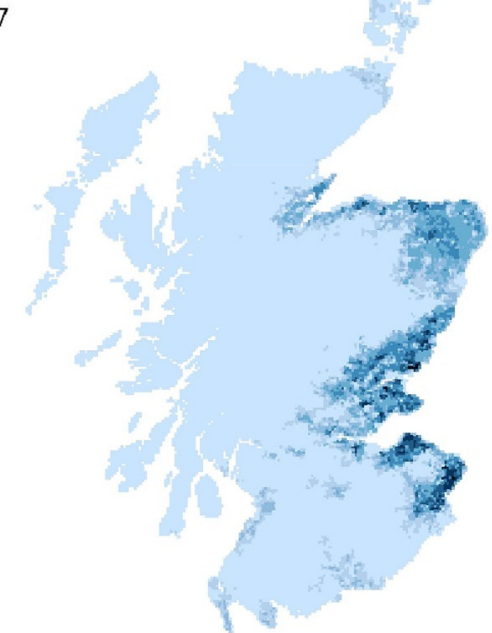

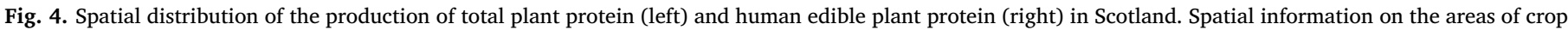
production and grassland was obtained from the EDINA (2018) agcensus database.

proportion of all produced animal protein. This is the case because land-based animal by-products cannot currently be used as livestock feed in the UK, so all edible protein from the production of these animals can only be targeted for human consumption (or pet food which is not considered in this study). In contrast, the by-products from farmed fish can be used for livestock (fish or land-based animals) feeding, and therefore the total, not only human-edible, protein output from salmon and trout is shown in the figure.
The main source of plant-based protein in Scotland is non-human edible roughage (including fresh grass, hay, grass in concentrates, grass silage, maize silage and barley straw), either grown specifically for livestock production, consumed through rough grazing, or obtained as co-product from cereal grain production. A more detailed breakdown of the human-edible protein is shown in Fig. 3. Cereals are the main potentially human-edible plant protein source, and of the animal-based protein production (including animals slaughtered in Scotland and 
those exported as live animals), protein obtained from the dairy systems is the biggest product group. The main protein output of the dairy system is milk, but this system also contributes to meat production (about $10 \%$ of the total protein obtained from the dairy system is meat). Fish farming (mainly salmon) and beef systems are also significant sources of animal-based protein, followed by smaller proportions of broiler chicken, sheep, chicken eggs and pigs (meat animals and slaughtered sows and boars).

Currently, only about $15 \%$ of plant protein production in Scotland is suitable for human consumption (Fig. 2), and the rest is applicable only as livestock feed, either directly or as co-products from distilleries/ breweries and vegetable oil production (mainly rapeseed). Overall, the total amount of the protein (either domestic or imported) fed to livestock is of the same magnitude as the total plant protein production. Further, nearly $70 \%$ of the livestock feed protein comes from roughage. This is a considerably high proportion, for example when compared to overall EU roughage consumption obtained from the EU Feed Protein Balance Sheet (European Commission, 2019). According to that report, only $45 \%$ of the protein fed to livestock in the EU is roughage-based. Further, the protein production in Scotland is spatially differentiated as a result of climatic and soil conditions. Human edible plant protein (predominantly cereals) is mostly produced in a relatively small area in eastern Scotland, generally on land 'capable of supporting arable agriculture' which covers only about $8 \%$ of the total land area of Scotland, while the remaining land provides mainly non-human edible (roughage) protein (Fig. 4). The combined area of managed grasslands and rough grazing was estimated to be about 4.3 million hectares (55\% of the land area of Scotland), according to the EDINA database.

The potentially human-edible plant protein production is dominated by two cereal species: barley and wheat (Fig. 3). Of these crops, barley is almost entirely used either in the drinks industry (distilleries and breweries) or in livestock feeding (NFU Scotland, 2019). Similarly, a significant proportion of wheat grown in Scotland is used for livestock feed and/or inputs for distilleries. For example, in pig and poultry production in the UK, wheat is the main feed ingredient and the most important source of dietary energy. Overall, co-products from distilleries represent a significant proportion of the total protein supply in Scotland. Based on the data obtained from the Scotch Whisky Association technical report (SWA, 2018), this proportion was estimated to be about $25 \%$ (nearly 70,000 tonnes) of all human or livestock edible plant protein production (Fig. 2).

These calculations demonstrate that the proportion of the human edible inputs in livestock production differs strongly between species (Table 1). Non-ruminant production (pigs and chicken) in Scotland is

Table 1

The intake $\left(1000 \mathrm{t} \mathrm{y}^{-1}\right)$ of protein coming different sources in the production of the main land-based livestock species in Scotland as estimated using the Scottish Agricultural Emission Model (SAEM). Potentially human edible inputs are shown in italics.

\begin{tabular}{lllll}
\hline & Cattle & Sheep & Pig & Chicken \\
\hline Wheat grains & 9 & 0 & 15 & 33 \\
Barley grains $_{\text {Maize grain }}^{\mathrm{a}}$ & 39 & 10 & 3 & 1 \\
Distillery/brewers grains $_{\text {Soya meal }}$ & 12 & 2 & 1 & 1 \\
Rapeseed $^{\mathrm{b}}$ & 30 & 0 & 0 & 0 \\
Roughage $^{\mathrm{c}}$ & 15 & 12 & 12 & 35 \\
Other $^{\mathrm{d}}$ & 49 & 2 & 13 & 17 \\
Total $^{\text {dotal }}$ & 568 & 271 & 0 & 0 \\
& 8 & 1 & 0 & 0 \\
& 730 & 298 & 44 & 87
\end{tabular}

a Includes gluten feed.

b Mainly rapeseed meal. A small amount of whole rapeseeds also included in chicken feed.

c Includes fresh grass, hay, grass in concentrates, grass silage, rough grazing, maize silage and straw.

d Includes fish meal, synthetics, molasses and beetpulp almost entirely dependent on potentially human-edible feed ingredients (mainly wheat and soya), while cattle production (especially suckler beef) is largely based on non-human edible feed (roughage). In fact, according to the data used in this study for the beef production systems in Scotland, the consumption of protein coming from potentially human edible crops (domestic or imported) by the animals is slightly lower (about 19,000 $\mathrm{t}^{-1}$ ) than the human edible protein output from beef cattle (about 21,000 $\mathrm{ty}^{-1}$, Fig. 3). In this sense, beef production can be seen to have a positive "net protein contribution" to the protein supply chain (Ertl et al., 2015; Baber et al., 2018; Mottet et al., 2017). It should be noted that the protein intake figures in Table 1 contain both imported and domestically produced feeds. Certain feed ingredients (mainly soya and maize grains) are all imported, and other ingredients may be either domestic or imported. The proportion of imports could not be specified here, and that was not the aim of this study either.

As stated above, one of the most critical global factors concerning the protein quality is supply of the essential amino acid lysine (Leinonen et al., 2019). Only certain agricultural products can be considered as primary sources of lysine for human consumption. These include animal products (meat, milk, fish and eggs) and some highlysine crops, mainly soya and other legumes such as beans and peas. These legumes account for only about $3 \%$ of the Scotland's total humanedible plant protein production (Figs. 2 and 3). Most of the other crops produced in Scotland have low lysine concentration, including cereals such as barley and wheat, or low overall protein concentration such as potato (Solanum tuberosum). Instead, the production of lysine-rich protein is currently dominated by livestock products milk, meat, fish and eggs. Based on the estimated protein outputs and the lysine concentration of each specific output, the total production of animal-based human edible lysine in Scotland was $10,400 \mathrm{t} \mathrm{y}^{-1}$ in 2015. For comparison, the plant-based lysine obtained from potential primary protein crops faba beans and field peas (Pisum sativum) was less than $600 \mathrm{t} \mathrm{y}^{-1}$, i.e. just over $5 \%$ of the livestock-based lysine production.

\subsection{Land use efficiency of protein production in scotland}

The land demand for current lysine produced in Scotland is presented in Fig. 5. The arable land requirement shown in this figure is separated between the area required for producing the potentially human edible plant-based inputs, and the area for producing nonhuman edible inputs coming from arable land (in this case agricultural by-products). Although different definitions of "human-edible" can be found in the literature (see discussion below), in this paper it indicates the crops that can be used directly for both human and livestock consumption, and excludes the feed coming from distillery and oil seed (rapeseed) by-products. The result shows that for livestock production, non-ruminant livestock species (pigs, chicken) have a relatively high land requirement for human edible inputs compared to ruminants per unit of lysine (or total protein) produced. The reason for this is that the production of non-ruminant species is dependent on high-quality feed ingredients such as cereals (as a feed energy source) and soya (as a source of feed protein) which could also be used directly in human nutrition.

The results of the linear programming procedure for energy and amino acid requirement show that a considerable amount of wheat (or other energy-rich food items) is needed to supplement the energy intake in both meat-based and domestic legume-based diet scenarios (Table 2). In the case of these specific "diets", high inclusion of cereals also ensures that the required intake of all other essential amino acids is fulfilled (especially sulfur amino acids in the case of bean diet). The results in Table 2 also show that since the land requirement for human-edible inputs is of a similar magnitude for beans and beef, and also their lysine/energy ratios are comparable, the magnitude of the total arable land use (when only human-edible inputs are included) is similar in both scenarios, and the differences are within the margin of uncertainty (see the Uncertainty Analysis section below). In addition to the 


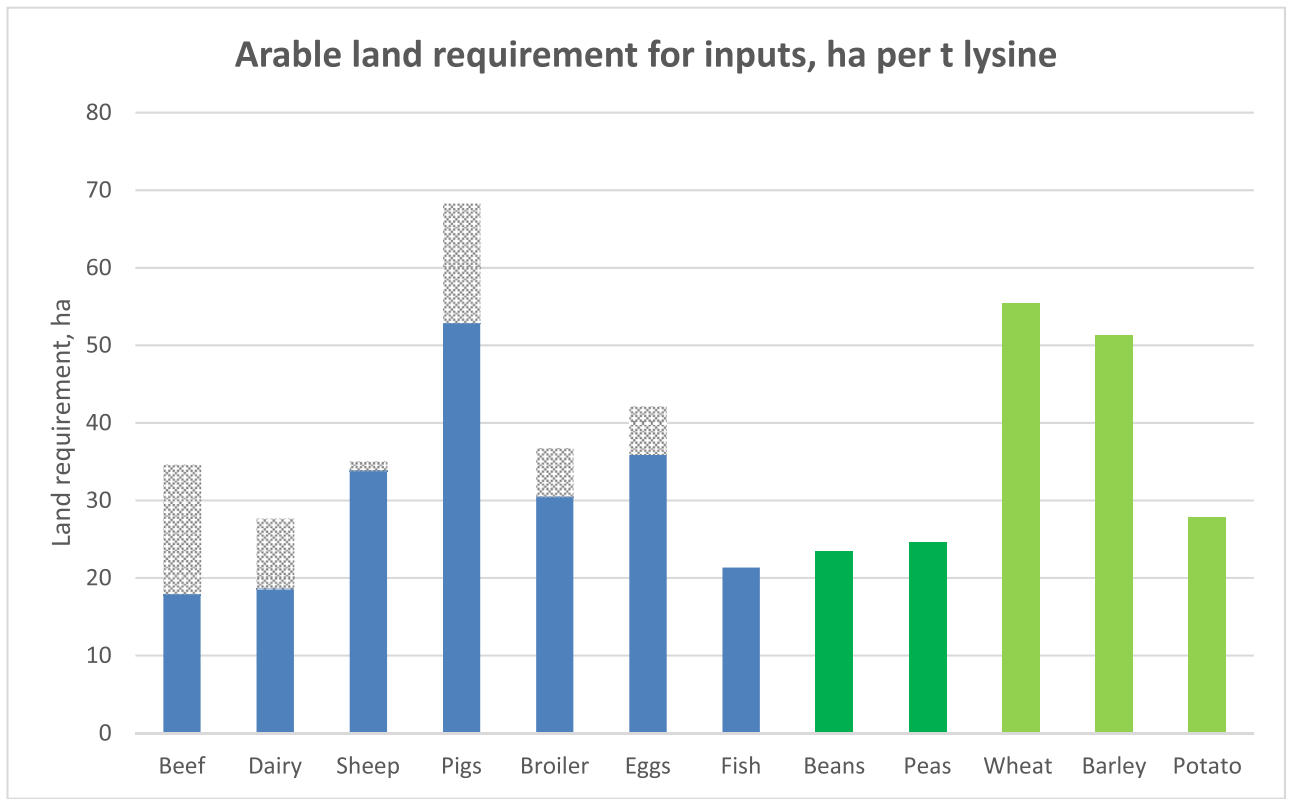

Fig. 5. The arable area required for producing the human edible inputs needed to produce one tonne of lysine from different plant and animal sources. The protein obtained from distillery and oil seed co-products is shown as dotted columns. Blue columns indicate animal species/products, green columns primary plant-based lysine sources and light green columns other crops that are not primary lysine sources. (For interpretation of the references to colour in this figure legend, the reader is referred to the Web version of this article.)
Scotland-based protein sources, the scenario based on imported soya as a lysine source is also presented in Table 2. It can be seen that also this scenario is comparable to other lysine production scenarios in terms of the land efficiency, despite the very high lysine yield of soya. The reason for this very similar land requirement between the soya scenario and the other scenarios is that the need for additional wheat as energy source is the highest in the soya-based scenario, due to the low energy concentration of soya in relation to its lysine content.

In Scotland, a significant part of cattle diets (especially in suckler beef production) are high-protein residues of distillation/brewing industries and rapeseed oil production, which complement the grassbased cattle industry. To demonstrate the importance of by-product use in cattle production, an alternative scenario is shown in Table 2, where the by-products in feed are replaced by other feed crops (in this case barley and soya). In practice, this would mean that an arable land area of a similar magnitude as the area currently providing the by-products would be needed to maintain the cattle production. As shown in the results, this option would considerably increase the overall land requirements for human-edible inputs in protein production.

\subsection{Uncertainty analysis}

As stated above, quantitative assessment of the uncertainties of the scenario outputs is not always feasible because the scenarios are very much based on qualitative, rather subjective choices, such as selection of the allocation methods, and the overall formulation of the scenarios. The consequences of such choices are discussed below. However, it is possible to roughly estimate the quantitative uncertainty for the main output variables (i.e. protein yield, and land requirement) in this study. For that purpose, the expected variation of the input variables as shown in Equation (3) were estimated as follows.

Probably the biggest source of uncertainty in the calculations is the human-edible fraction of the crops. In this study, the 'medium scenario' by Ertl et al. (2015) was used in the calculations. This scenario was then compared to the 'low' and 'high' scenarios by Ertl et al. (2015), and an average $20 \%$ difference between the scenarios was found. This value was used as an estimate of the $\mathrm{CoV}_{H E}$. For variation in the crop yields, Scottish Government (2019) data series from 2004 to 2015 were used for the yield of main arable crops crown considered in this study, and an average year-to-year variation of $6 \%$ was found, and this value was used as an estimate of $\operatorname{CoV}_{Y}$. For the variation in protein and lysine concentration, the Feedipedia (2018) database was used. This database shows the standard deviation of numerous studies where the nutritional value of crops has been determined. Based on those data, the average values of 7\% and 6\% were used for $\operatorname{CoV}_{P r}$ and $\operatorname{CoV}_{L y s}$, respectively.

As an outcome of the uncertainty analysis, an overall uncertainty

Table 2

Lysine $\left(\mathrm{g}\right.$ person $\left.{ }^{-1} \mathrm{~d}^{-1}\right)$ and energy $\left(\mathrm{kJ}\right.$ person $\left.{ }^{-1} \mathrm{~d}^{-1}\right)$ intake and land requirement $\left(\mathrm{m}^{2}\right.$ person $\left.{ }^{-1} \mathrm{~d}^{-1}\right)$ in simplified dietary scenarios.

\begin{tabular}{|c|c|c|c|c|}
\hline & Meat-based scenario & Meat-based scenario, no by-products & Domestic legume scenario & Soya-based scenario \\
\hline Lysine intake from beef, $g$ person ${ }^{-1} \mathrm{~d}^{-1}$ & 0.819 & 0.819 & 0 & 0 \\
\hline Lysine intake from beans, $g$ person ${ }^{-1} \mathrm{~d}^{-1}$ & 0 & 0 & 0.820 & 0 \\
\hline Lysine intake from soya, $g$ person ${ }^{-1} \mathrm{~d}^{-1}$ & 0 & 0 & 0 & 0.798 \\
\hline Lysine intake from wheat, $g$ person ${ }^{-1} \mathrm{~d}^{-1}$ & 1.281 & 1.281 & 1.280 & 1.302 \\
\hline Total lysine intake, $g$ person ${ }^{-1} \mathrm{~d}^{-1}$ & $2.10^{\mathrm{a}}$ & $2.10^{\mathrm{a}}$ & $2.10^{\mathrm{a}}$ & $2.10^{\mathrm{a}}$ \\
\hline Total protein intake, $g$ person ${ }^{-1} \mathrm{~d}^{-1}$ & 68 & 68 & 71 & 59 \\
\hline Energy intake from beef, $\mathrm{kJ}$ person ${ }^{-1} \mathrm{~d}^{-1}$ & 691 & 691 & 0 & 0 \\
\hline Energy intake from beans, $\mathrm{kJ}$ person ${ }^{-1} \mathrm{~d}^{-1}$ & 0 & 0 & 699 & 0 \\
\hline Energy intake from soya, $\mathrm{kJ}$ person ${ }^{-1} \mathrm{~d}^{-1}$ & 0 & 0 & 0 & 555 \\
\hline Energy intake from wheat, $\mathrm{kJ}$ person ${ }^{-1} \mathrm{~d}^{-1}$ & 8559 & 8559 & 8551 & 8695 \\
\hline Total energy intake, $\mathrm{kJ}_{\text {person }}{ }^{-1} \mathrm{~d}^{-1}$ & $9250^{\mathrm{a}}$ & $9250^{\mathrm{a}}$ & $9250^{\mathrm{a}}$ & $9250^{\mathrm{a}}$ \\
\hline Land requirement for human edible inputs, $\mathrm{m}^{2}$ person ${ }^{-1} \mathrm{~d}^{-1}$ & 0.856 & 0.992 & 0.901 & 0.840 \\
\hline Land requirement for by-products, $\mathrm{m}^{2}$ person ${ }^{-1} \mathrm{~d}^{-1}$ & 0.137 & 0 & 0 & 0 \\
\hline Land requirement for roughage, $\mathrm{m}^{2}$ person ${ }^{-1} \mathrm{~d}^{-1 \mathrm{~b}}$ & 8.6 & 8.6 & 0 & 0 \\
\hline
\end{tabular}

\footnotetext{
a Equals the recommended daily intake.
}

b Managed grassland and rough grazing. 
( $\operatorname{CoV}_{L y s Y}$ ) of $23 \%$ was found. This level of uncertainty indicates that the overall magnitude of the land requirement of lysine production in Scotland can be rather reliably estimated. However, it can be also seen that the differences in the requirement of land use for human edible inputs between most of the scenarios explored in this study remain within the margin of uncertainty. Therefore, very detailed comparison between those scenarios is not feasible; instead, the result can be interpreted so that approximately the same level land use can be achieved when using different options for production of human-edible protein.

\section{Discussion}

In the analyses carried out in this study, we have adopted an approach where we formulate a series of simplified dietary scenarios and apply them to explore the consequences of production of some typical food items on the requirement of agricultural land use. By using this approach, it is possible to quantify the land requirement of different potential protein sources separately, and more importantly, also their indirect effects as a result of changing requirements for additional food items needed to keep the dietary amino acid and energy concentrations balanced. It should also be noted that the scenario results presented here are fully additive and can be used to explore different combined diet scenarios as well. For example, if we assume a "flexitarian" diet with $50 \%$ meat and $50 \%$ beans as primary lysine sources, the total land requirement for that kind of diet would simply be the average of the meat-based and domestic legume-based scenarios.

Overall, the dietary scenarios included in this study show that the land requirement for human food supply is dominated by the energy supply (in this case wheat) rather than the lysine (protein) supply. For example, in the bean-based scenario, the wheat production covers $79 \%$ of the needed land area, and the bean production only $21 \%$. For the soya-based scenario, this difference is even bigger ( $86 \%$ wheat vs. $14 \%$ soya). Further, while the land requirement for human-edible feed would be much higher if replacing the beef by meat from non-ruminant livestock (Fig. 5), the relative differences in the overall land use would be smaller, because the need for additional energy source (e.g. cereals) would still remain. It should also be noted that if other, lower yield crop species are used as energy source instead of wheat, the overall land requirement would increase considerably. Therefore, any 'real' diet with multiple energy sources is likely to have a much higher land use compared to the theoretical minima explored in this study.

It appears that the current capacity to replace animal protein production with high quality (lysine-rich) plant protein production in Scotland is rather limited. Globally, protein obtained from leguminous crop species has been considered as a potential alternative to animalbased protein as a lysine source, and as stated above, currently soya beans are by far the biggest global source of such protein. However, in northern and western European countries, including Scotland, growing of soya is very much restricted by climate. Some soya is currently grown in the UK for forage use, but the cultivation area is still minimal. Although reasonable grain yields have been achieved in field experiments in Scotland (James Hutton Institute, personal communication), there is currently no commercial soya grain production. It is likely that development of new varieties is needed to make soya a potentially viable option for protein source in Scotland (Poehlman, 1987). Due to the current limitations in soya production in Scotland and the currently limited availability of other high-quality plant proteins, the plant-based lysine production in this region should be based on leguminous crops other than soya, such as field beans and field peas, although the lysine yield of those legumes per unit land area is globally much lower compared to soya (Squire et al., 2019; Zander et al., 2016).

To replace all animal-based lysine produced in Scotland (i.e. lysine coming from land-based animals and from fish production), around 200,000 ha more land for growing legumes per year (based on the current Scottish yields) would be needed to produce the corresponding amount of lysine from beans or peas. It should be noted that a higher area than this can be released from the arable human-edible livestock feed production area (including feed for both land-based animals and fish production), which was estimated in this study to be more than 250,000 ha. However, it could be expected that this area would be only partly suitable for growing beans and peas for human consumption (Squire et al., 2019). If the reduction of cultivation of feed crops will be targeted to marginal areas that are not well suited for legumes, it would be possible that this will result in increased land competition between the new protein crops and other human-edible arable crops. It should also be noted that several years' gap between legume crops at a single site is needed to reduce the risk of crop disease. This will further reduce the legume production potential in Scotland.

One way to increase the sustainability of protein production is via the improvement of land use efficiency of livestock production, and especially reduction of the consumption of animal feed coming from land that could otherwise be used for production of crops consumed directly by humans. A practical solution for this would be the replacement of potentially human-edible feedstuff by feed ingredients that are not suitable for human consumption and would need no additional agricultural land for their production (Schader et al., 2015; Karlsson and Röös, 2019). In practice, such ingredients would be mainly agricultural co-products.

The potential land use benefits of ruminant production have been discussed also in earlier studies (e.g. van Zanten et al., 2016; Mottet et al., 2017; Baber et al., 2018), suggesting that grazing ruminants can be more efficient converters of vegetal protein into animal protein than monogastric animals. Although the latter are generally more efficient in the total protein and energy conversion (e.g. Shepon et al., 2016), they require larger amounts of human-edible feed ingredients such as cereals and soya. However, it is not always straightforward to specify the difference between 'human-edible' and 'non-human edible' feed ingredients. For example, Mottet et al. (2017) noted that although soya bean meal cannot be considered as a food item suitable for human consumption, its raw material soya beans (and their protein content) can be targeted to human food market. Many agricultural co-products can be seen even more problematic in this comparison. For example, although distillery co-products currently have limited applicability as human food (Wilhelmson et al., 2009), the raw materials (e.g. barley and wheat) can potentially be utilized in the food industry. Despite such a potential, in this study the distillery co-products used as livestock feed were classified as 'non-human edible'. The reason for this is that the cereals grown specifically for alcohol production do not currently contribute to the food vs. feed competition (Makkar, 2018; Karlsson and Röös, 2019). Part of the outputs of those cereals will enter the human food chain (i.e. carbohydrates used to produce alcohol), but the remaining components, including protein, will be excluded from human consumption and can be considered as non-avoided food waste. This is analogous to the rapeseed production in Scotland since also in this case only part of the commodity (oil) will be used for humans, while the remaining co-product (meal) is non-human edible.

Although livestock industry provides a 'traditional' end use for these co-products as feed, alternative uses have also emerged during recent years, including the use of co-products in renewable energy generation in anaerobic digestion and combined heat and power plants and recovering the remaining nutrients to be used as plant fertilisers (Styles et al., 2015; Leinonen et al., 2018a). Although such uses can be seen environmentally beneficial, e.g. through reduction of fossil energy use, they would necessarily remove valuable protein from the food chain.

The whole idea of the separation of the land use between 'humanedible' and 'non-human edible' production originates from an assumption that ruminants can utilize land that would otherwise be 'wasted', at least when human nutrition is concerned. It should, however, be noted that alternative, environmentally beneficial uses for the grasslands and areas of rough grazing that are currently used for ruminant production have also been proposed, for example, afforestation that could contribute to carbon sequestration (Bastin et al., 2019; 
Mader, 2019), or protein conversion through biorefineries, transferring the currently non-human edible protein directly to human or non-ruminant livestock consumption (Corona et al., 2018). Such alternative uses could potentially make the ruminant livestock production less beneficial in terms of its inputs to human food chain. Recent, laboratory-scale studies have given promising results on the opportunities to utilize the grasslands in Scotland for converting the grass protein to high-quality human-edible form (Lawson et al., 2020). However, the yields of recovered protein per hectare are still expected to be quite low, and the required handling of the biomaterial makes this process rather energy intensive. Further, it is possible that the future grass biorefinery would be mainly limited to managed grasslands in lowland Scotland, due to economic reasons, and therefore livestock could remain the only option for utilizing the upland rough grazing areas for human-edible protein production.

Furthermore, it could be questioned whether any fundamental changes in food production chains (e.g. replacing one production system with other at a certain region, or drastically improving the production in current systems) would be rapid enough to be able to efficiently mitigate the alarming climate change during the coming decades. Although successful attempts have been made to reduce the emissions arising from agricultural production through improving production efficiency (e.g. Tallentire et al., 2016; Leinonen, 2019), the required timescale brings additional challenges. As an example, crop and animal breeding and GM technologies have considerably increased the quantity and quality of food production, but breeding programs have both technical and biological limits (e.g. Ferreira et al., 2005; Wang and Galili, 2016; Tallentire et al., 2018), and it may take decades before the improved breeds/varieties can achieve their mitigation potential at a global-scale. Similarly, new technologies such as biorefineries need still further development (e.g. Xiu and Shabbazi, 2015) and public acceptability may limit the utilization of their outputs as food.

In order to consider the wider environmental consequences (e.g. global warming, eutrophication, biodiversity etc.) of alternative uses of grasslands, similarly as in the case of any global-level change in food systems, it would be necessary to apply holistic assessment methods, such as systems-based modelling (e.g. Mottet et al., 2017), consequential Life Cycle Assessment (Earles and Halog, 2011) and probably global economic models. For example, assessing the effects of land use changes on the global GHG emissions is not straightforward, since such changes affect the global supply and demand of agricultural and other commodities and the associated emission related to production and transport of them. Such assessments were beyond the scope of this study, but it would necessarily to consider them in further studies on the consequences of dietary changes. It is important to keep in mind that any local changes in the food system have necessarily global consequences (Springmann et al., 2018). For example, reducing the protein production (or food production in general) in one area would necessarily increase the pressure to increase the production elsewhere to meet the increasing global demand for food. The same is valid with land use. It can be argued that any agricultural production anywhere in the world increases the global land use pressure, and therefore the indirect land use change effects are now commonly taken into account for example in agricultural life cycle assessment modelling (Audsley et al., 2009; Cederberg et al., 2011; Schmidt et al., 2015).

Overall, it should be kept in mind that local changes in the structure of food industry (e.g. plant-based vs. animal-based protein production) are unlikely to have impact on global changes in the patterns of food consumption and dietary preferences. A continuing global trend is increasing demand for animal-based protein (FAOSTAT, 2018), which makes the efficient use of agricultural land for food production very challenging. A shift towards more land use-efficient or low-emission protein production would not be possible without global changes in consumer demand (e.g. Reynolds et al., 2014; Aleksandrowics et al., 2016; Willet et al., 2019; Wrieden et al., 2019). Although these changes can be motivated by either increased environmental, animal welfare or health concerns of the general public, or other factors including environmental taxes or other public policy interventions, globally such changes are expected to be slow, keeping the demand for livestock products at a high level also in the near future.

\section{Conclusions}

The results obtained in this study show that the land use efficiency of high-quality protein in a country like Scotland can be improved, and this can be achieved with plant-based (protein crops) and/or animal based (forage/by-product consuming ruminants) production. The high GHG emissions intensity and other environmental impacts of ruminant livestock have been generally recognised, and there is pressure towards replacing red meat with other protein sources in global food production. Such a trend would shift the plant protein demand from nonhuman edible protein (e.g. forage) towards potentially human edible proteins (used either directly for human consumption or as non-ruminant livestock feed). This would have large-scale land use consequences and could potentially increase land use pressure. The results also show that potential changes in the dietary protein source have, after all, rather limited effect on the overall requirement of land use for food production. The land requirement for human food consumption is dominated by crops used as sources of dietary energy, rather than amino acids, and therefore land use consequences of dietary changes should be explored at the level of the whole diets, rather than concentrating on the use of single food items.

\section{Declaration of competing interest}

The authors declare that they have no known competing financial interests or personal relationships that could have appeared to influence the work reported in this paper

\section{Acknowledgements}

This work was supported by the Scottish Government, through the Rural Affairs and the Environment Portfolio Strategic Research Programme 2016-2021, WP 1.4 'Integrated and Sustainable Management of Natural Assets', and the SEFARI Gateway project, "Pathways toward a sustainable protein economy". RMR and PPMI are also supported by the EU-H2020 funded project TRUE (www.trueproject.eu), Grant Agreement number 727973.

The grid square agricultural census data, as converted by Edinburgh University Data Library, are derived from data obtained for recognised geographies from The Scottish Government (formerly SEERAD), the Department of Environment, Food and Rural Affairs (DEFRA) and The Welsh Assembly Government and are covered by (C) Crown Copyright.

\section{Appendix A. Supplementary data}

Supplementary data to this article can be found online at https:// doi.org/10.1016/j.gfs.2020.100386.

\section{References}

Aleksandrowics, L., Green, R., Joy, E.J.M., Smith, P., Haines, A., 2016. The impacts of dietary change on greenhouse gas emissions, land use, water use and health: a systematic review. PloS One 11, e0165797. https://doi.org/10.1371/journal.pone. 0165797.

Audsley, E., Brander, M., Chatterton, J., Murphy-Bokern, D., Webster, C., Williams, A., 2009. How Low Can We Go? an Assessment of Greenhouse Gas Emissions from the UK Food System and the Scope to Reduce Them by 2050. WWF-UK.

SWA, 2018. Scotch whisky cereals technical note. The Scotch whisky association. https:// www.scotch-whisky.org.uk/media/1361/cereals_technical_note_3rd_edition_final_ 090818-1.pdf, Accessed date: 30 July 2019.

Baber, J.R., Sawyer, J.E., Wickersham, T.A., 2018. Estimation of human-edible protein conversion efficiency, net protein contribution, and enteric methane production from 
beef production in the United States. Transl. Anim. Sci. 2, 439-450. https://doi.org/ 10.1093/tas/txy086.

Bastin, J.-F., Finegold, Y., Garcia, C., Mollicone, D., Rezende, M., Routh, D., Zohner, C.M., Crowther, T.W., 2019. The global tree restoration potential. Science 365, 76-79. https://doi.org/10.1126/science.aax0848.

British Nutrition Foundation, 2016. Nutrition requirements. https://www.nutrition.org. uk/healthyliving/resources/nutritionrequirements.html.

Cederberg, C., Martin Persson, U., Neovius, K., Molander, S., Clift, R., 2011. Including carbon emissions from deforestation in the carbon footprint of Brazilian beef. Environ. Sci. Technol. 45, 1773-1779. https://doi.org/10.1021/es103240z.

Chaudhary, A., Gustafson, D., Mathys, A., 2018. Multi-indicator sustainability assessment of global food systems. Nat. Commun. 9, 848. https://doi.org/10.1038/s41467-01803308-7.

Corona, A., Ambye-Jensen, M., Vega, G.C., Hauschild, M.Z., Birkved, M., 2018. Technoenvironmental assessment of the green biorefinery concept: combining process simulation and life cycle assessment at an early design stage. Sci. Total Environ. 635, 100-111. https://doi.org/10.1016/j.scitotenv.2018.03.357.

Earles, J.M., Halog, A., 2011. Consequential life cycle assessment: a review. Int. J. Life Cycle Assess. 16, 445-453. https://doi.org/10.1007/s11367-011-0275-9.

EDINA, 2018. EDINA Agcensus. http://agcensus.edina.ac.uk/, Accessed date: 27 June 2018.

Ertl, P., Klocker, H., Hörtenhuber, S., Knaus, W., Zollitsch, W., 2015. The net contribution of dairy production to human food supply: the case of Austrian dairy farms. Agric. Syst. 137, 119-125. https://doi.org/10.1016/j.agsy.2015.04.004.

European Commission, 2019. EU feed protein balance Sheet. https://ec.europa.eu/ agriculture/sites/agriculture/files/cereals/balance-sheets/protein/eu-feed-proteinbalance-sheet_2017-18.pdf.

FAO, 2017. Global Livestock Environmental Assessment Model Version 2.0 Model Description Revision 4, June 2017. Food and Agriculture Organization of the United Nations (FAO), Rome.

FAO, 2018. Global Livestock Environmental Assessment Model (GLEAM). Food and Agriculture Organization of the United Nations (FAO), Rome. http://www.fao.org/ gleam/en/, Accessed date: 27 June 2018.

FAO/WHO/UNU, 2007. Protein and Amino Acid Requirements in Human Nutrition. Report of a Joint FAO/WHO/UNU Expert Consultation (WHO Technical Report Series 935). . http://www.who.int/nutrition/publications/nutrientrequirements/WHO_ TRS 935/en/, Accessed date: 19 November 2018.

FAOSTAT, 2018. Food and Agriculture Data. The Food and Agriculture Organization of the United Nations (FAO). http://www.fao.org/faostat/en/, Accessed date: 19 November 2018.

Feedipedia, 2018. Animal Feed Resources Information System. https://www.feedipedia. org/, Accessed date: 19 November 2018.

Ferreira, R.R., Varisi, V.A., Meinhardt, L.W., Lea, P.J., Azevedo, R.A., 2005. Are highlysine cereal crops still a challenge? Braz. J. Med. Biol. Res. 38, 985-994. https://doi. org/10.1590/S0100-879X2005000700002.

Foyer, C.H., Lam, H.M., Nguyen, H.T., Siddique, K.H., Varshney, R.K., Colmer, T.D., Cowling, W., Bramley, H., Mori, T.A., Hodgson, J.M., Cooper, J.W., Miller, A.J., Kunert, K., Vorster, J., Cullis, C., Ozga, J.A., Wahlqvist, M.L., Liang, Y., Shou, H., Shi, K., Yu, J., Fodor, N., Kaiser, B.N., Wong, F.L., Valliyodan, B., Considine, M.J., 2016. Neglecting legumes has compromised human health and sustainable food production. Nat. Plants 2, 16112. https://doi.org/10.1038/nplants.2016.112.

Gerber, P.J., Steinfeld, H., Henderson, B., Mottet, A., Opio, C., Dijkman, J., Falcucci, A., Tempio, G., 2013. Tackling Climate Change through Livestock - A Global Assessment of Emissions and Mitigation Opportunities. Food and Agriculture Organization of the United Nations (FAO), Rome.

IPCC, 2018. Global warming of $1.5^{\circ} \mathrm{C}$. Intergovernmental Panel on climate change. http://www.ipcc.ch/report/sr15/, Accessed date: 19 November 2018.

JHI, 2019. Land Capability for Agriculture in Scotland. James Hutton Institute. https:// www.hutton.ac.uk/learning/exploringscotland/land-capability-agriculture-scotland, Accessed date: 26 July 2019

Karlsson, J.O., Röös, E., 2019. Resource-efficient use of land and animals-environmental impacts of food systems based on organic cropping and avoided food-feed competition. Land Use Pol. 85, 63-72. https://doi.org/10.1016/j.landusepol.2019.03.035.

Lawson, D., Sellars, A., Leinonen, I., 2020. Appraisal of Herbage Bioprocessing. Scottish Funding Council, Universities Innovation Fund, Final Report. SRUC, Edinburgh, UK.

Leinonen, I., 2019. Achieving environmentally sustainable livestock production. Sustainability 11, 246. https://doi.org/10.3390/su11010246.

Leinonen, I., MacLeod, M., Bell, J., 2018a. Effects of alternative uses of distillery byproducts on the greenhouse gas emissions of scottish malt whisky production: a system expansion approach. Sustainability 10, 1473. https://doi.org/10.3390/ su10051473.

Leinonen, I., Eory, V., MacLeod, M., 2018b. Applying a process-based livestock model to predict spatial variation in agricultural nutrient flows in Scotland. J. Clean. Prod. 209, 180-189. https://doi.org/10.1016/j.jclepro.2018.10.236.

Leinonen, I., Iannetta, P.P.M., Rees, R.M., Russell, W., Watson, C., Barnes, A.P., 2019. Lysine supply is a critical factor in achieving sustainable global protein economy. Front. Sust. Food Syst. 3, 27. https://doi.org/10.3389/fsufs.2019.00027.

Lin, B.B., 2011. Resilience in agriculture through crop diversification: adaptive management for environmental change. Bioscience 61, 183-193. https://doi.org/10. 1525/bio.2011.61.3.4

Lizarazo, C.I., 2015. Nutritive quality and protein production from grain legumes in a boreal climate. J. Sci. Food Agric. 95, 2053-2064. https://doi.org/10.1002/jsfa. 6920.

MacLeod, M., Sykes, A., Leinonen, I., Eory, V., 2017. Quantifying the Greenhouse Gas Emission Intensity of Scottish Agricultural Commodities: CXC Project; Technical Report. SRUC, Edinburgh, UK.
MacLeod, M.J., Vellinga, T., Opio, C., Falcucci, A., Tempio, G., Henderson, B., Makkar, H., Mottet, A., Robinson, T., Steinfeld, H., Gerber, P.J., 2018. Invited review: a position on the global livestock environmental assessment model (GLEAM). Animal 12, 383-397. https://doi.org/10.1017/S1751731117001847.

Mader, S., 2019. Plant trees for the planet: the potential of forests for climate change mitigation and the major drivers of national forest area. Mitig. Adapt. Strategies Glob. Change. https://doi.org/10.1007/s11027-019-09875-4. (Published online).

Makkar, H.P.S., 2018. Review: feed demand landscape and implications of food-not feed strategy for food security and climate change. Animal 12, 1744-1754. https://doi. org/10.1017/S175173111700324X.

Marine Scotland Science, 2017. Scottish fish Farm production Survey 2016. https://www. gov.scot/publications/scottish-fish-farm-production-survey-2016/, Accessed date: 30 July 2019.

Mottet, A., de Haan, C., Falcuccia, A., Tempio, G., Opio, C., Gerber, P., 2017. Livestock: on our plates or eating at our table? A new analysis of the feed/food debate. Glob. Food Secur. 14, 1-8. https://doi.org/10.1016/j.gfs.2017.01.001.

Moya, M., 2016. Lysine genetically enriched cereals for improving nutrition in children under 5years in low- and middle- income countries. J. Nutr. Health Food Eng. 5, 583-586. https://doi.org/10.15406/jnhfe.2016.05.00164.

NFU Scotland, 2019. What we produce. https://www.nfus.org.uk/farming-facts/whatwe-produce.aspx, Accessed date: 30 July 2019.

Nijdam, D., Rood, T., Westhoek, H., 2012. The price of protein: review of land use and carbon footprints from life cycle assessments of animal food products and their substitutes. Food Pol. 37, 760-770. https://doi.org/10.1016/j.foodpol.2012.08.002.

Poehlman, J.M., 1987. Breeding soybeans. Breeding Field Crops. Springer, Dordrecht. https://doi.org/10.1007/978-94-015-7271-2_17.

Reynolds, C.J., Buckley, J.D., Weinstein, P., Boland, J., 2014. Are the dietary guidelines for meat, fat, fruit and vegetable consumption appropriate for environmental sustainability? A review of the literature. Nutrients 6, 2251-2265. https://doi.org/10 3390/nu6062251.

Ritchie, H., Reay, D.S., Higgins, P., 2018. Beyond calories: a holistic assessment of the global food system. Front. Sust. Food Syst. 2, 57. https://doi.org/10.3389/fsufs. 2018. 00057.

Röös, E., Bajželj, B., Smith, P., Patel, M., Little, D., Garnett, T., 2017. Protein futures for Western Europe: potential land use and climate impacts in 2050. Reg. Environ. Change 17, 367-377. https://doi.org/10.1007/s10113-016-1013-4.

Schader, C., Muller, A., Scialabba, N.E.-H., Hecht, J., Isensee, A., Erb, K.-H., Smith, P. Makkar, H.P.S., Klocke, P., Leiber, F., Schwegler, P., Stolze, M., Niggli, U., 2015. Impacts of feeding less food-competing feedstuffs to livestock on global food system sustainability. J. R. Soc. Interface 12, 20150891. https://doi.org/10.1098/rsif.2015. 0891.

Schmidt, J.H., Weidema, B.P., Brandao, M., 2015. A framework for modelling indirect land use changes in Life Cycle Assessment. J. Clean. Prod. 99, 230-238. https://doi org/10.1016/j.jclepro.2015.03.013.

Scottish Government, 2019. Economic report on scottish agriculture. https://www2.gov. scot/Topics/Statistics/Browse/Agriculture-Fisheries/PubEconomicReport, Accessed date: 30 July 2019

Shepon, A., Eshel, G., Noor, E., Milo, R., 2016. Energy and protein feed-to-food conversion efficiencies in the US and potential food security gains from dietary changes. Environ. Res. Lett. 11, 105002. https://doi.org/10.1088/1748-9326/11/10/105002.

Springmann, M., Clark, M., Mason-D’Croz, D., Wiebe, K., Bodirsky, B.L., Lassaletta, L., de Vries, W., Vermeulen, S.J., Herrero, M., Carlson, K.M., Jonell, M., Troell, M., DeClerck, F., Gordon, L.J., Zurayk, R., Scarborough, P., Rayner, M., Loken, B., Fanzo, J., Godfray, H.C.J., Tilman, D., Rockström, J., Willett, W., 2018. Options for keeping the food system within environmental limits. Nature 562, 519-525. https://doi.org/ 10.1038/s41586-018-0594-0.

Squire, G.R., Quesada, N., Begg, G.S., Iannetta, P.P.M., 2019. Transitions to greater legume inclusion in cropland: defining opportunities and estimating benefits for the nitrogen economy. Food Energy Secur. https://doi.org/10.1002/fes3.175. (Published online).

SRUC, 2019. Crop advise directory. https://www.sruc.ac.uk/directory/24/crop_advice_ directory, Accessed date: 30 July 2019.

Styles, D., Gibbons, J., Williams, A.P., Stichnothe, H., Chadwick, D.R., Healey, J.R., 2015. Cattle feed or bioenergy? Consequential life cycle assessment of biogas feedstock options on dairy farms. GCB Bioenergy 7, 1034-1049. https://doi.org/10.1111/gcbb. 12189.

Tallentire, C.W., Leinonen, I., Kyriazakis, I., 2016. Breeding for efficiency in the broiler chicken. A review. Agron. Sustain. Dev. 36, 66. https://doi.org/10.1007/s13593016-0398-2.

Tallentire, C.W., Leinonen, I., Kyriazakis, I., 2018. Artificial selection for improved energy efficiency is reaching its limits in broiler chickens. Sci. Rep. 8, 1168. https://doi.org/ 10.1038/s41598-018-19231-2

USDA, 2018. Food Composition Databases. United States Department of Agriculture, Agricultural Research Service. https://ndb.nal.usda.gov/ndb/, Accessed date: 19 November 2018.

van Zanten, H.H.E., Mollenhorst, H., Klootwijk, C.W., van Middelaar, C.E., de Boer, I.J.M., 2016. Global food supply: land use efficiency of livestock systems. Int. J. Life Cycle Assess. 21, 747-758. https://doi.org/10.1007/s11367-015-0944-1.

Wang, W., Galili, G., 2016. Transgenic high-lysine rice - a realistic solution to malnutrition? J. Exp. Bot. 67, 4009-4011. https://doi.org/10.1093/jxb/erw254.

Westhoek, H., Rood, T., van de Berg, M., Janse, J., Nijdam, D., Reudink, M., Stehfest, E., 2011. The Protein Puzzle. The Consumption and Production of Meat, Dairy and Fish in the European Union. PBL Netherlands Environmental Assessment Agency, The Hague.

Wilhelmson, A., Lehtinen, P., von Weymarn, N., Itävaara, M., Sibakov, J., Heiniö, R.-L., Forssell, P., Buchert, J., 2009. Future applications for brewers' spent grain. New Food 
12, 59-61. Accessed. https://www.newfoodmagazine.com/article/269/futureapplications-for-brewers-spent-grain/, Accessed date: 30 July 2019.

Wilkinson, J.M., 2011. Re-defining efficiency of feed use by livestock. Animal 5, 1014-1022. https://doi.org/10.1017/S175173111100005X.

Willett, W., Rockström, J., Loken, B., Springmann, M., Lang, T., Vermeulen, S., Garnett, T., Tilman, D., DeClerck, F., Wood, A., Jonell, M., Clark, M., Gordon, L.J., Fanzo, J., Hawkes, C., Zurayk, R., Rivera, J.A., De Vries, W., Sibanda, L.M., Afshin, A.,

Chaudhary, A., Herrero, M., Agustina, R., Branca, F., Lartey, A., Fan, S., Crona, B., Fox, E., Bignet, V., Troell, M., Lindahl, T., Singh, S., Cornell, S.E., Reddy, K.S., Narain, S., Nishtar, S., Murray, C.J.L., 2019. Food in the Anthropocene: the EAT-Lancet Commission on healthy diets from sustainable food systems. Lancet 393, 447-492. https://doi.org/10.1016/S0140-6736(18)31788-4. 2019.

Wrieden, W., Halligan, J., Goffe, L., Barton, K., Leinonen, I., 2019. Sustainable diets in the
UK-developing a systematic framework to assess the environmental impact, cost and nutritional quality of household food purchases. Sustainability 11, 4974. https:// doi.org/10.3390/su11184974.

Xiu, S., Shahbazi, A., 2015. Development of green biorefinery for biomass utilization: a review. Trends. Renew. Energy 1, 4-15. https://doi.org/10.17737/tre.2015.1.1.008.

Ytrestøyl, T., Aas, T.S., Åsgård, T., 2015. Utilisation of feed resources in production of Atlantic salmon (Salmo salar) in Norway. Aquaculture 448, 365-374. https://doi. org/10.1016/j.aquaculture.2015.06.023.

Zander, P., Amjath-Babu, T.S., Preissel, S., Reckling, M., Bues, A., Schläfke, N., Kuhlman, T., Bachinger, J., Uthes, S., Stoddard, F., Murphy-Bokern, D., Watson, C., 2016. Grain legume decline and potential recovery in European agriculture: a review. Agron. Sustain. Dev. 36, 26. https://doi.org/10.1007/s13593-016-0365-y. 